\title{
Investigation of Antioxidant, In-vitro Cytotoxic, and In-vivo Antitumor Effects of Leaf Extracts of Annona Reticulata
}

\author{
Shashwata Biswas ${ }^{1}$, Mohammad Shahriar², Jahan Ara Khanam³ ${ }^{3}$ Chowdhury Rafiqul Ahsan ${ }^{1 *}$ \\ ${ }^{1}$ Department of Microbiology, University of Dhaka, Dhaka, Bangladesh, ${ }^{2}$ Department of Pharmacy, University of Asia Pacific, Dhanmondi, Dhaka, Bangladesh, \\ ${ }^{3}$ Department of Biochemistry and Molecular Biology, Rajshahi University, Rajshahi, Bangladesh
}

\begin{abstract}
This study was carried out to evaluate the antioxidant, brine shrimp lethality, bioassay and antitumor effects of $\mathbf{n}$ hexane, petroleum ether, methanol and chloroform extracts of Annona reticulata leaves. All extracts demonstrated good cupric reducing activity with increasing concentrations keeping methanol extract at the top and n-hexane extract at the second position. The methanol extract was found to have the highest antioxidant capacity $28 \pm 26.88$ followed by $\mathrm{n}$-hexane $16.95 \pm 11.39$ and chloroform $12.85 \pm 10.32$ in the form of $\mathrm{mg}$ of ascorbic acid equivalent per gram of crude extract. The methanol extract also showed the highest values of $2.41 \pm 0.963 \mathrm{mg}$ of gallic acid equivalent phenolic content and $6.54 \pm 4.08 \mathrm{mg}$ of quercetin equivalent flavonoid content per $\mathrm{g}$ of crude extract. In the brine shrimp lethality bioassay, $\mathrm{LC}_{50}$ values of methanol, chloroform, petroleum ether, and $\mathrm{n}$-hexane extracts were found to be $1.084 \mu \mathrm{g} / \mathrm{ml}, 1.096 \mu \mathrm{g} / \mathrm{ml}, 1.995 \mu \mathrm{g} / \mathrm{ml}$ and $3.126 \mu \mathrm{g} / \mathrm{ml}$, respectively. These findings suggest that $A$. reticulata leaves can be a good source of antioxidants and possess significant cytotoxic effect. In a narrow spectrum investigation on antitumor activity of the extracts, we found that the methanol extract inhibited the tumor growing process (control group, chloroform group and petroleum ether group showed significant rise in body weight; i.e., $8 \%-14 \%$ of initial weight compared to that of methanol group showing a rise of $0.45 \%-0.94 \%$ of initial weight) and improved ILS (Percentage Increase in Life Span) with increasing doses (Doses of $50 \mathrm{mg} / \mathrm{kg}, 100 \mathrm{mg} / \mathrm{kg}$ and $200 \mathrm{mg} / \mathrm{kg}$ showed ILS values of $13.70 \%, 19.20 \%$ and $21.92 \%$, respectively) to some extent when compared with control group and groups receiving other extracts.
\end{abstract}

Key words: Annona reticulata, reducing power, brine shrimp, anti-tumor effect

\section{Introduction}

Bangladesh is a rich and prestigious heritage of herbal medicine. Only a few of the 250 plants that are being used to treat various diseases, have undergone phytochemical studies. The crushed leaves of A. reticulata are used as poultice on boils, ulcers and abscesses and leaf decoction is used as vermifuge. The tree is not especially attractive. It is erect, with a rounded or spreading crown and trunk 10 to 14 in $(25-35 \mathrm{~cm})$ thick. Height ranges from 15 to $35 \mathrm{ft}$ (4.5-10 m). The ill-smelling leaves are deciduous, alternate, oblong or narrow-lanceolate, 4 to 8 in (10$20 \mathrm{~cm}$ ) long, 3/4 to 2 in $(2-5 \mathrm{~cm})$ wide, with conspicuous veins.

Free radicals have been accused of initiating many serious diseases $^{1-3}$. These free radicals drive oxidative stress and transform the pathophysiological condition of the patient by acting on immune system. It has been known that phenolic and flavonoid compounds of the plant extracts are responsible for antioxidant and antibacterial effects ${ }^{4-6}$.

Taking all the above concerns into account, we conducted this study to find out more about $A$. reticulata leaves. We studied the antioxidant effects with presence of such phytochemical constituents as equivalent to standards in different extracts, the cytotoxic effect, hence antitumor effect.

\section{Materials and Methods}

Plant materials

The leaves of A.reticulata were collected from Naogaon, Bangladesh, in November, 2011. A voucher specimen for this plant has been maintained in Bangladesh National Herbarium, Dhaka, Bangladesh (Accession no.3799).

The sun dried and powdered leaves (76 g) of A. reticulata were successively extracted in a Soxhlet extractor at elevated temperature using $200 \mathrm{ml}$ of distilled n-hexane $(40-60)^{\circ} \mathrm{C}$ which was followed by petroleum ether, methanol, and chloroform. All extracts were filtered individually through filter paper and poured on petri dishes to evaporate the liquid solvents from the extract to get dry extracts. The dry crude extracts were weighed and stored in air-tight container with necessary markings for identification and kept in a refrigerator for future investigations.

Brine shrimp lethality bioassay

Brine shrimp lethality bioassay technique ${ }^{7,8}$ was applied for the determination of general toxic properties of the plant extracts. Dimethyl sulfoxide (DMSO) solutions of the samples were applied against Artemia salina in a 1-day in vitro assay. For the 
experiment, $4 \mathrm{mg}$ of each of the n-hexane, petroleum ether, methanol and chloroform soluble fractions were dissolved in DMSO and solutions of varying concentrations (400, 200, 100, 50, 25, 12.50, 6.25, 3.125, 1.563, 0.781 ìg/ml) were obtained by serial dilution technique using DMSO. Vincristine sulphate was used as positive control.

Total Phenolics analysis (Total phenolic content of leaf extracts of $A$. reticulata was measured employing the method involving Folin-Ciocalteu reagent ${ }^{9}$ as oxidizing agent and gallic acid as standard).

\section{Determination of Total Flavonoids Content}

Aluminium chloride colorimetric method ${ }^{10}$ was used for Flavonoids determination. One $\mathrm{ml}$ of the plant extracts/standard of different concentration solutions was mixed with $3 \mathrm{ml}$ of methanol, $0.2 \mathrm{ml}$ of $10 \%$ aluminum chloride, $0.2 \mathrm{ml}$ of $1 \mathrm{M}$ potassium acetate and $5.6 \mathrm{ml}$ of distilled water. Quercetin was used as standard. The solution was kept at room temperature for $30 \mathrm{~min}$; the absorbance of the reaction mixture was measured at $415 \mathrm{~nm}$ with a spectrophotometer against methanol, which was served as blank. The total content of flavonoid compounds in leaf methanol extracts in quercetin equivalents was calculated by the following equation:

$C=(c \times V) / m$

Where; $\mathrm{C}=$ total content of flavonoid compounds in $\mathrm{mg}$ of quercetin equivalent $/ \mathrm{gm}$ plant extract, $\mathrm{c}=$ the concentration of quercetin established from the calibration curve in $\mathrm{mg} / \mathrm{ml}, \mathrm{V}=$ the volume of extract in $\mathrm{ml}$ and $\mathrm{m}=$ the weight of crude plant extract in gm.

\section{Determination of Total Antioxidant Capacity}

The total antioxidant capacity was evaluated by the phosphomolybdenum method ${ }^{11}$. Three hundred microlitre of extract/standard of different concentration solutions was mixed with $1 \mathrm{ml}$ of $0.333 \% \mathrm{H}_{2} \mathrm{SO}_{4}, 1 \mathrm{ml}$ of $0.004 \mathrm{M}$ ammonium molybdate and $1 \mathrm{ml}$ of $0.02295 \mathrm{M} \mathrm{NaH}{ }_{2} \mathrm{PO}_{4}$ and the mixtures were incubated at $95^{\circ} \mathrm{C}$ for 90 minutes. Absolute ethanol was served as blank and was treated in the same way as the sample. Ascorbic acid was used as standard. After cooling to room temperature, the absorbance of each sample and standard was measured at $695 \mathrm{~nm}$ against the blank. The antioxidant activity is expressed as the number of equivalents of ascorbic acid and was calculated by the following equation:

$A=(c \times V) / m$

Where, $\mathrm{A}=$ total content of antioxidant compounds in $\mathrm{mg}$ of ascorbic acid equivalent /gm plant extract, $\mathrm{c}=$ the concentration of ascorbic acid established from the calibration curve in mg/ $\mathrm{ml}, \mathrm{V}=$ the volume of extract in $\mathrm{ml}$ and $\mathrm{m}$ = the weight of crude plant extract in gm.

\section{Cupric Reducing Antioxidant Capacity (CUPRAC)}

The assay was conducted as described previously ${ }^{12}$. To $0.5 \mathrm{ml}$ of plant extract or standard of different concentration solutions,
$1 \mathrm{ml}$ of copper (II) chloride solution (0.01 M prepared from $\mathrm{CuCl}_{2} \cdot 2 \mathrm{H}_{2} \mathrm{O}$ ), $1 \mathrm{ml}$ of ammonium acetate buffer at $\mathrm{pH} 7.0$ and $1 \mathrm{ml}$ of neocaproin solution $(0.0075 \mathrm{M})$ were mixed. The final volume of the mixture was adjusted to $4.1 \mathrm{ml}$ by adding $0.6 \mathrm{ml}$ of distilled water and the total mixture was incubated for 1 hour at room temperature. Then the absorbance of the solution was measured at $450 \mathrm{~nm}$ using a spectrophotometer against blank. Butylated hydroxytoluene (BHT) was used as standard.

\section{Animals and Treatment}

Swiss albino mice (male) weighing 15-25 g were used for the research. The mice were purchased from the Animal Research Branch of the International Centre for Diarrhoeal Disease and Research, Bangladesh (ICDDR,B) Mohakhali, Dhaka. The animals were maintained in the animal facility of the Department of Microbiology, University of Dhaka and had free access to feed and water ad libitum. The animals were acclimatized to laboratory condition for one week prior to experiments.

\section{Measurement of Antitumor Activity}

The antitumor activity was tested according to method described previously ${ }^{13}$, with some modifications, when all the mice were divided into eight groups. Each group comprised of 4 mice $(n=4)$, each mouse was weighed and received $1 \times 10^{6}$ EAC cells/mouse. This day was considered as day - 0. From the next day (Day - 1), group - 1,2, and 3 received (i.p.) methanol extract dissolved in DMSO at equally divided doses of $50 \mathrm{mg} / \mathrm{kg}, 100 \mathrm{mg} / \mathrm{kg}$ and $200 \mathrm{mg} / \mathrm{kg}$ for 5 consecutive days, respectively. Similarly, group - 4 and 5 received (i.p.) petroleum ether extracts dissolved in DMSO at equally divided doses of $50 \mathrm{mg} / \mathrm{kg}$ and $100 \mathrm{mg} / \mathrm{kg}$ and group - 6 and 7 received (i.p.) same doses of chloroform extract for 5 consecutive days. The control group received nothing (positive control) or DMSO (negative control) for the same duration. All the mice were weighed on day - 5 and day - 10 and after day - 10, their length of survival was monitored. The weight and survival time readings of the treated group were compared with those of control. The mean survival time and percentage increase in life span were calculated using following equations:

$\Sigma$ survival time (days) of each mouse in a group

Mean survival time (MST) $=\frac{\text { Total number of mice }}{\text { MST of treated group }}$
MST of control group

\section{Results and Discussion}

Brine Shrimp Lethality Bioassay

The median lethal concentration $\left(\mathrm{Lc}_{50}\right)$ of the test samples after 24 hours was obtained by a plot of percentage of the shrimps died against the logarithm of the sample concentration (toxicant concentration) and the best-fit line was obtained from the curve data by means of regression analysis. Vincristine 
Sulphate (VS) was used as positive control and the $\mathrm{LC}_{50}$ was found $0.323 \mu \mathrm{g} / \mathrm{ml}$. Compared with the negative control, VS (positive control) gave significant mortality and the $\mathrm{LC}_{50}$ values of the different extracts were compared with negative control.

The $\mathrm{LC}_{50}$ values of methanol, chloroform, petroleum ether, and n-hexane were found to be $1.084 \mu \mathrm{g} / \mathrm{ml}, 1.096 \mathrm{ig} / \mathrm{ml}$, $1.995 \mu \mathrm{g} / \mathrm{ml}$, and $3.126 \mu \mathrm{g} / \mathrm{ml}$ respectively (Table 1 ). However, varying degree of lethality of Artemia salina was observed with exposure to different dose levels of the test samples ranging from $0.781-400 \mu \mathrm{g} / \mathrm{ml}$. There was no mortality in the negative control groups indicating that the test as a valid one and the results obtained were only due to the activity of the test agents.

Table 1. $L C_{50}$ values of leaf extracts of $A$. reticulata and standard

\begin{tabular}{lccc}
\hline Standard andextracts & Regression line & $\mathrm{R}^{2}$ & $\mathrm{LC}_{50}(\mu \mathrm{g} / \mathrm{ml})$ \\
\hline Vincristine sulphate & $\mathrm{y}=29.79 \mathrm{x}+64.62$ & 0.927 & 0.323 \\
Methanol extract & $\mathrm{y}=19.32 \mathrm{x}+51.89$ & 0.918 & 1.084 \\
Chloroform extract & $\mathrm{y}=19.12 \mathrm{x}+55.14$ & 0.885 & 1.096 \\
Petroleum ether extract & $\mathrm{y}=23.15 \mathrm{x}+44.11$ & 0.951 & 1.995 \\
n-hexane extract & $\mathrm{y}=28.38 \mathrm{x}+31.58$ & 0.970 & 3.126 \\
\hline
\end{tabular}

Total phenolics analysis

All the extracts of $A$. reticulata were tested for total phenolic content and results were expressed as gallic acid equivalent (GAE) per gram of plant extract. Among all extracts the highest phenolic content was found in methanol extract $(2.41 \pm 0.963$ $\mathrm{mg}$ of $\mathrm{GAE} / \mathrm{gm}$ of extracts) followed by petroleum ether extract ( $1.721 \pm 0.137 \mathrm{mg}$ of GAE/gm of extractives). Significant amount of phenolic compounds were also present in n-hexane extract $(1.703 \pm 0.153 \mathrm{mg}$ of $\mathrm{GAE} / \mathrm{gm}$ of extractives) and chloroform extract ( $1.675 \pm 0.091 \mathrm{mg}$ of GAE/ gm of extracts) (Table 2). Total phenolic contents of the extracts were found to decrease in follwing order: Methanol extract $>$ Petroleum ether extract $>$ n-hexane extract $>$ Chloroform extract (Figure 1).

Table 2. Total phenolic contents in different extracts of $A$. reticulata leaves

\begin{tabular}{lc}
\hline Extracts & $\begin{array}{c}\text { Total phenolic contents } \\
\text { (mg of gallic acid equivalent } \\
\text { per gram of crude extract) }\end{array}$ \\
\hline Methanol & $2.41 \pm 0.963$ \\
Petroleum ether & $1.721 \pm 0.137$ \\
n-hexane & $1.703 \pm 0.153$ \\
Chloroform & $1.675 \pm 0.091$ \\
\hline
\end{tabular}

Values are the mean of duplicate experiments and represented as mean \pm SD.

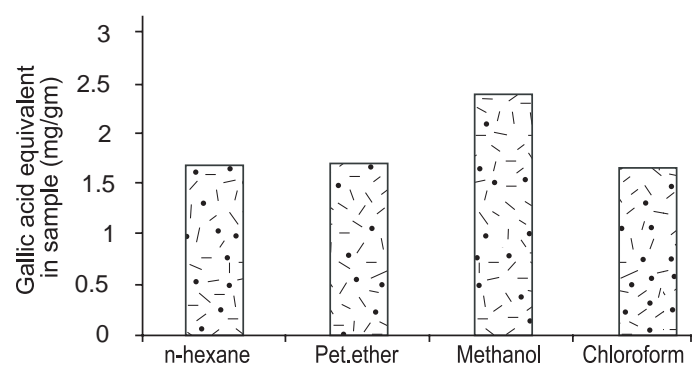

Figure 1: Presence of total phenolic contents in different extracts of $A$. reticulata leaves

\section{Total Flavonoid Content}

Aluminium chloride colorimetric method was used to determine the total flavonoid contents of the different extracts of $A$. reticulata leaves. Total flavonoid contents was calculated using the standard curve of quercetin $\left(y=0.004 x-0.038 ; R^{2}=0.996\right)$ and was expressed as quercetin equivalents (QE) per gram of the plant extract. Methanol extract of $A$. reticulata was found to contain the highest amount of flavonoid (Table 3 ). Flavonoid contents of the extracts were found to decrease in the following order: Methanol extract $>$ Chloroform extract $>$ n-hexane extract $>$ Petroleum ether extract (Figure 2).

Table 3. Total flavonoid contents in different extracts of A. reticulata leaves

\begin{tabular}{lc}
\hline Extracts & $\begin{array}{c}\text { Total flavonoid contents } \\
\text { (mg of quercetin equivalent } \\
\text { per gram of crude extract) }\end{array}$ \\
\hline Methanol & $6.54 \pm 4.08$ \\
Chloroform & $4.78 \pm 2.2$ \\
n-hexane & $4.75 \pm 2.82$ \\
Petroleum ether & $3.8 \pm 1.53$ \\
\hline
\end{tabular}

Values are the mean of duplicate experiments and represented as mean \pm SD

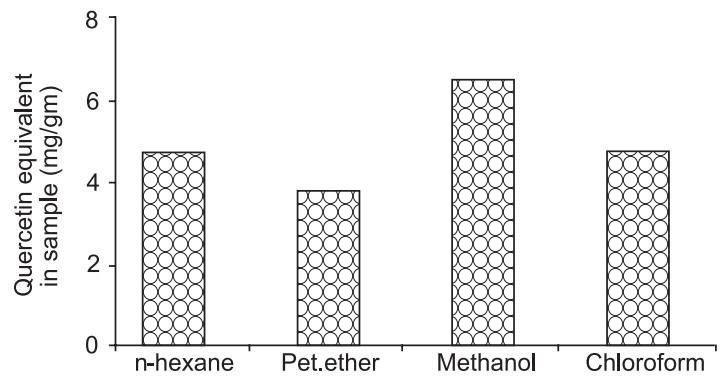

Figure 2: Presence of total flavonoid contents in different extracts of $A$. reticulata leaves

Total Antioxidant Capacity

Total antioxidant capacity of the different extracts of $A$. reticulata leaves was evaluated by the phosphomolybdenum method and was expressed as ascorbic acid equivalents (AAE) per gram of plant extract. Total antioxidant capacity of the test samples was calculated using the standard curve of ascorbic acid $\left(\mathrm{y}=0.001 \mathrm{x}-0.021 ; \mathrm{R}^{2}=0.993\right)$. Methanol extract of $A$. 
reticulata was found to possess the highest total antioxidant capacity (Table 4). Total antioxidant capacity of the extracts was found to decrease in the following order: Methanol extract $>$ n-hexane extract $>$ Chloroform extract $>$ Petroleum ether extract (Figure 3).

Table 4. Total antioxidant capacity in different extracts of A. reticulata leaves

\begin{tabular}{lc}
\hline Extracts & $\begin{array}{c}\text { Total antioxidant capacity } \\
\text { (mg of ascorbic acid equivalent } \\
\text { per gram of crude extract) }\end{array}$ \\
\hline Methanol & $28 \pm 26.88$ \\
n-hexane & $16.95 \pm 11.39$ \\
Chloroform & $12.85 \pm 10.32$ \\
Petroleum ether & $6.6 \pm 1.1$ \\
\hline
\end{tabular}

Values are the mean of duplicate experiments and represented as mean \pm SD

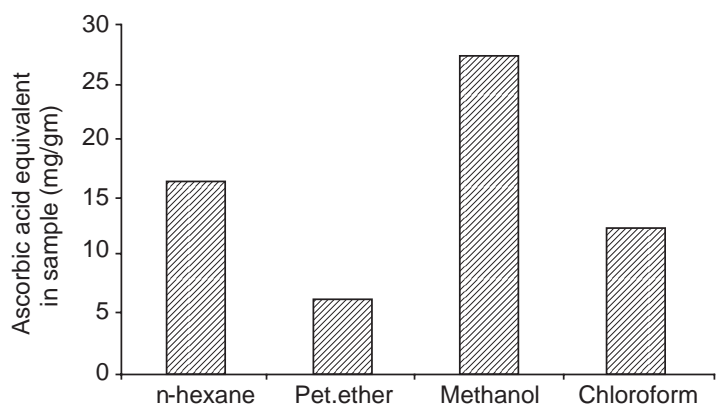

Figure 3. Presence of total antioxidant contents in different extracts of A. reticulata leaves

\section{Cupric Reducing Antioxidant Capacity (CUPRAC)}

Reduction of $\mathrm{Cu} 2+$ ion to $\mathrm{Cu}+$ was found to rise with increasing concentrations of the different extracts. The standard (BHT) showed highest reducing capacity. Among the extracts the methanol extract of $A$. reticulata showed maximum reducing capacity that is comparable to BHT (Figure 4).

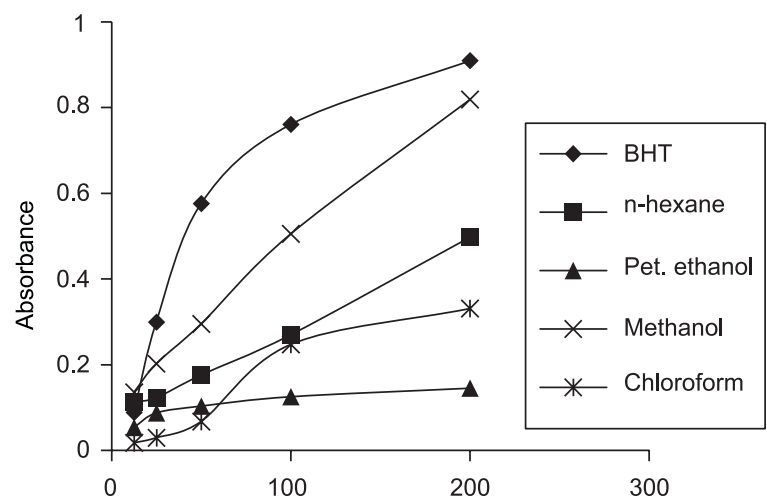

Figure 4. Comparison of Cupric Reducing Antioxidant Capacity of A. reticulata leaf extracts with that of BHT (Standard)

\section{Antitumor Activity}

After treatment with various concentrations of different extracts for 5 consecutive days and further 5 days observation, mice those were in control group, chloroform group, and petroleum ether group showed significant rise in body weight ( $8 \%-14 \%$ of weight on day - 1) compared to that of methanol group $(0.45 \%$ - $0.94 \%$ of weight on day - 1) (Figure 5). Mice receiving methanol extract showed increased percentage of weight gain with decreasing dose $(50 \mathrm{mg} / \mathrm{kg}-0.94 \% ; 100 \mathrm{mg} / \mathrm{kg}-0.74 \%$, and $200 \mathrm{mg} / \mathrm{kg}-0.45 \%)$.

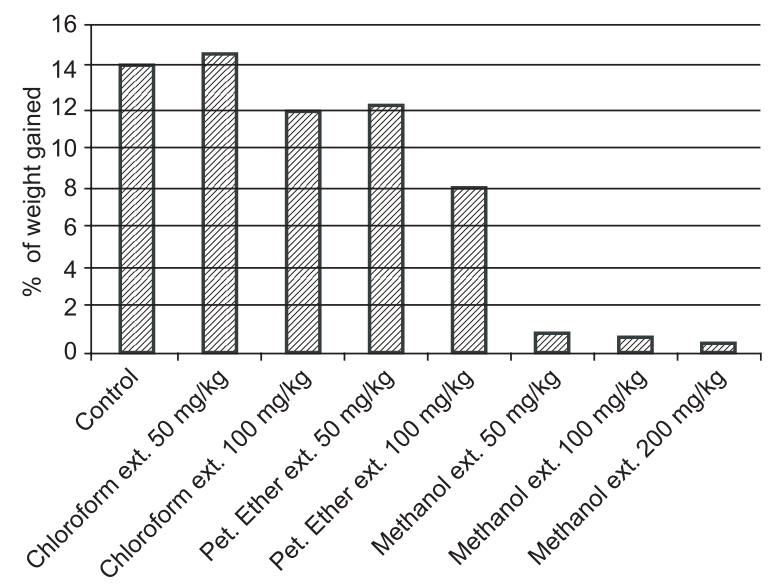

Figure 5. Comparison of \% of weight gain between control and treatment group

Percentage increase in life span (ILS) was also evident in mice receiving methanol extracts when compared with control. Mice receiving methanol extracts at doses of $50 \mathrm{mg} / \mathrm{kg}, 100 \mathrm{mg} / \mathrm{kg}$, and $200 \mathrm{mg} / \mathrm{kg}$ showed ILS values of $13.70 \%, 19.20 \%$, and $21.92 \%$, respectively, when compared to control (Figure 6).

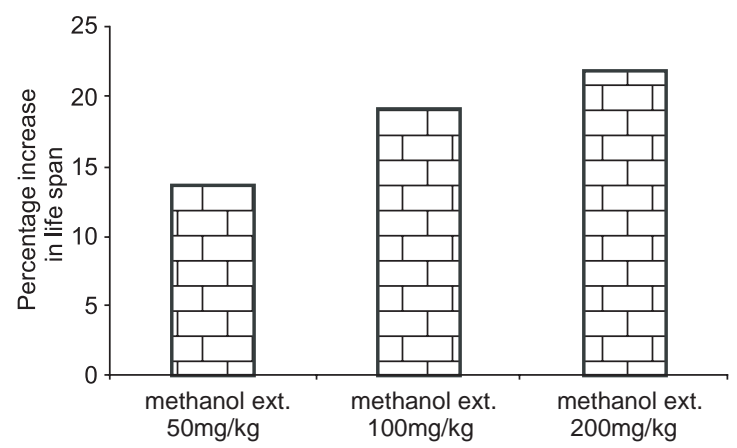

Figure 6. Percentage increase in life span (ILS) of mice receiving methanol extract of $A$. reticulata leaves

\section{Conclusion}

All the conducted experiments in the present study are based on crude extract and are considered to be preliminary and more sophisticated research is necessary to reach a concrete conclusion about the findings. To sum up, these findings together demonstrate that Annona reticulata is an excellent plant candidate for further investigation of individual compounds, their 
in-vivo antioxidant, and antitumor activity and different antioxidant and antitumor mechanisms. It also appears to be a promising candidate from which specific antioxidant bioactive products could be developed. Therefore, in depth extensive study should be done to sort out bioactive compounds of A.reticulata.

\section{References}

1. Malorni W, Rivabene R, Lucia BM, Ferrara R, Mazzone AM, Cauda R and Paganelli R. 1998. The role of oxidative imbalance in progression to AIDS effect of the thiol supplier $N$-acetylcysteine. AIDS Research and Human Retroviruses. 14(17): 1589-1596.

2. Robert A and Meunier B. 1998. Is alkylation the main mechanism of action of the antimalarial drug artemisi-nin? Chemical Society Review Articles. 27(4): 273-274.

3. Shah PM. 2005. The need for new therapeutic agents: what is in the pipeline? Clinical Microbiology and Infection. 11(3): 36-42.

4. Da-Silva JFM, De-Souza MC, Matta SR, De-Andrade MR and Vidal FVN. 2006. Correlation analysis between phenolic levels of brazilian propolis extracts and their antimicrobial and antioxidant activities. Food Chemistry. 99: 431-435.

5. Majhenic L, Skerget M and Knez Z. 2007. Antioxidant and antimicrobial activity of guarana seed extracts. Food Chemistry. 104(3): 1258-1268.

6. Pereira JA, Oliveira I, Sousa A, Valentao P and Andrade PB 2007. Walnut (Juglans regia L.) leaves: phenolic compounds, antibacterial activity and antioxidant potential of different cultivars. Food and Chemical Toxicology. 45: 2287-2295.

7. Meyer BN, Ferrigni NR, Putnam JE, Jacobsen JB, Nicholsand DE and Mclaughlin, JL. 1982. Brine shrimp; a convenient general bioassay for active plant constituents. Planta Med. 45: 31-34.

8. Maclaughlin JL, Anderson JE, Rogers LL. 1998. The use of biological assays to evaluate botanicals. Drug Info Jour. 32: 513-524.

9. Skerget M, Kotnik P, Hadolin M, Hras A, Simonic M and Knez Z. 2005. Phenols, proanthocyanidins, flavones and flavonols in some plant materials and their antioxidant activities. Food Chemistry 89: 191-198.

10. Wang SY and Jiao H. 2000. Correlation of antioxidant capacities to oxygen radical scavenging enzyme activities in blackberry. Journal of Agricultural and Food Chemistry. 48(11): 5672-5676.

11. Prieto P, Pineda M and Aguilar M. 1999. Spectrophotometric quantitation of antioxidant capacity through the formation of a phosphomolybdenum complex: specific application to the determination of vitamin E. Analytical Biochemistry. 269(2): 337-341.

12. Apak R., Güçlü K, Özyürek M and Karademir SE. 2004. Novel total antioxidant capacity index for dietary poly-phenols and vitamins $\mathrm{C}$ and $\mathrm{E}$, using their cupric ion reducing capability in the presence of neocaproine: CUPRAC Method. Journal of Agricultural and Food Chemistry. 52(26): 7970-7981.

13. Mazumder UK, Gupta M, Maiti S and Mukherjee M. 1997. Antitumor activity of Hygrophilaspinosa on ehrlich ascites carcinoma and sarcoma-180 induced mice. Indian J Expt Biol. 35: 473-477. 